\title{
Combustion Approach for Downsizing: the IFP Concept
}

\author{
A. Pagot ${ }^{1}$, A. Duparchy' ${ }^{1}$ X. Gautrot ${ }^{1}$, P. Leduc ${ }^{1}$ and G. Monnier ${ }^{1}$ \\ 1 Institut français du pétrole, 1 et 4, avenue de Bois-Préau, 92852 Rueil-Malmaison Cedex - France \\ e-mail: alexandre.pago@@ifp.fr - alexandre.duparchy@ifp.fr - xavier.gautroł@ifp.fr - pierre.leduc@iff.fr - gaetan.monnier@ifp.fr
}

Résumé - L'approche combustion de l'écosuralimentation : le concept IFP — Le transport individuel doit faire face à de plus en plus de contraintes. Dans le passé, les normes et les constructeurs automobiles se sont avant tout attachés à réduire les émissions de polluants. Même si la réduction de consommation a toujours été un axe majeur de recherche, elle est devenue prioritaire à cause de l'effet de serre du $\mathrm{CO}_{2}$. A long terme, l'hybridation présente le plus fort potentiel mais à court terme le downsizing permettra une réduction importante de la consommation des véhicules essence.

Pour profiter au mieux de la réduction de cylindrée, l'IFP a développé un concept s'appuyant notamment sur le balayage pour, à la fois, offrir une très bonne résistance au cliquetis et un couple élevé à bas régime. Cette approche a initialement été développée en combinant l'injection directe d'essence (GDI), une distribution variable et des carters turbine à flux séparés (pour les moteurs à 4 cylindres). Cette technologie permet également de développer la stratification de richesse pour des combustions à la stoechiométrie grâce à la double injection. Cette stratification permet d'améliorer la résistance au cliquetis des moteurs mais augmente fortement les émissions de polluants dans la cas d'un système d'injection conventionnel. L'IFP a mis un ouvre une solution prometteuse qui à permit à un moteur de 21 de cylindrée ayant un rapport volumétrique de 11.2:1 d'atteindre 1.89 MPa de PME à 1500 tr $/ \mathrm{min}$.

Le facteur coût est omniprésent dans l'industrie automobile. L'IFP y est sensibilisé et a pris en compte cette contrainte en proposant deux solutions concrètes pour réduire le coût des moteurs essence suralimentés. La première étape a été de supprimer les carters turbine à flux séparés pour revenir à des étages turbine conventionnels tout en conservant le balayage sur les moteurs à 4 cylindres. Les résultats ont prouvé que cette technologie était un très bon compromis coût / performance. Le moteur de 1.81 de cylindrée atteint ainsi soit $2.4 \mathrm{MPa}$ de PME à $2000 \mathrm{tr} / \mathrm{min}$ et $90 \mathrm{~kW} / \mathrm{l}$ soit $2.4 \mathrm{MPa}$ de PME à $1400 \mathrm{tr} / \mathrm{min}$ et $83 \mathrm{~kW} / \mathrm{l}$. Cette dernière version a également été évaluée en fonctionnement entièrement stoechiométrique avec une température entrée turbine de $1050{ }^{\circ} \mathrm{C}$. La puissance maximale est alors de $73 \mathrm{~kW} / \mathrm{l}$ pour une consommation spécifique très attractive de $260 \mathrm{~g} / \mathrm{kWh}$.

Pour les petits moteurs essence, l'aspect coût est encore plus discriminant ; l'IFP a donc commencé à développer un concept de moteur à balayage et à injection indirecte d'essence. Les résultats actuels confirment le potentiel de l'approche et sa capacité à ne pas court-circuiter de carburant, ce qui ouvre de nouvelles perspectives. 


\begin{abstract}
Combustion Approach for Downsizing: the IFP Concept - Individual transport is facing more and more constraints. In the past decade regulations and car manufacturers have focused above all on decreasing pollutant emissions. Even though it has always been a major part of research, fuel economy has now become the number one priority because of the $\mathrm{CO}_{2}$ greenhouse effect. In the long term, hybridisation presents the best potential but in the short term, downsizing will allow for a substantial reduction in gasoline engine fuel consumption.
\end{abstract}

To obtain the full benefits from downsizing, IFP has developed a combustion concept based on high knock resistance and high low-end torque potential due to scavenging. This approach has initially been developed by combining gasoline direct injection (GDI) variable valve timing and twin-scroll technologies (for 4-cylinder engines). This technology is used to develop lambda one partly stratified combustion due to split injection. These stratified mixtures improve engine knock resistance but with conventional injection systems they induce severe drawbacks on pollutant emissions. IFP's answer to this problem has shown very high potential according to the $1.89 \mathrm{MPa}$ at $1500 \mathrm{rpm}$ reached by a 2 litre engine with compression ratio of 11.2 .

In the car industry, cost is one of the most restrictive criteria. IFP has taken this into account when proposing 2 concrete solutions to reduce the cost of turbocharged gasoline engines. The first step was to replace twin-scroll turbine housings by mono-scroll turbines. Then the challenge was to maintain scavenging on 4-cylinder engines. Results have shown that this approach seems to be a very good trade-off between cost and performance. The 1.8 litre engine performs either 2.4 MPa BMEP at $2000 \mathrm{rpm}$ and $90 \mathrm{~kW} / \mathrm{l}$ or $2.4 \mathrm{MPa} \mathrm{BMEP}$ at $1400 \mathrm{rpm}$ and $83 \mathrm{~kW} / \mathrm{l}$. In the latter case, the engine has also been evaluated in full lambda one operation with maximum upstream turbine temperature of $1050^{\circ} \mathrm{C}$. Even if limited by lambda one combustion, maximum power density reaches $73 \mathrm{~kW} / \mathrm{l}$ with a very attractive $260 \mathrm{~g} / \mathrm{kWh}$ specific fuel consumption.

As the cost of small gasoline engines is critical, IFP has started to develop the scavenging process in the case of port fuel injection. Current results show that it is possible to avoid fuel by-pass with a specifically designed engine that points the way to very interesting prospects.

\section{INTRODUCTION}

Nowadays more than ever, road transport is required to reduce its pollutant emissions. Local pollution mainly due to $\mathrm{NOx}, \mathrm{HC}, \mathrm{CO}$ and particulates is a major problem that regulations have partly solved by forcing car manufacturers to produce environmentally friendly engines. $\mathrm{CO}_{2}$ emissions, identified as one cause of the greenhouse effect, are more problematic as they are the result of hydrocarbon combustion. Consequently, the only way to reduce $\mathrm{CO}_{2}$ emissions is to reduce vehicle fuel consumption.

In this context Diesel engines present the highest thermal efficiency, but gasoline ones present two main advantages. Firstly, thanks to three-way catalysis (in the case of lambda one combustion), after-treatment is highly efficient, reliable and a low energy consumer. Secondly they are significantly cheaper to manufacture, and their cost is at least less than half of a Diesel engine.

IFP considers one of the major strategies for gasoline engines is to increase thermal efficiency while preserving these two benefits as far as possible. Downsizing is compatible with both. Of course, stratified combustion with dedicated NOx after-treatment is another interesting way but world-wide compatibility of such an approach is harder due to disparities in sulphur content of gasoline around the world.
In fact, turbocharging a gasoline engine while reducing its cubic capacity - downsizing - is a major way to reduce $\mathrm{CO}_{2}$ emissions. Considering the efficiency chain that leads to the final global efficiency of an engine, and by comparing it with a conventional naturally aspirated gasoline engine, this approach reduces pumping and friction losses (see Fig. 1 and Fig. 2). Today, the question is to reap the benefit in terms of fuel consumption while preserving a high level of driveability, fun to drive and reasonable production costs for the engine. In fact, turbocharging allows for high torque and power densities but has some drawbacks on low-end torque and knock sensitivity that may have an impact on compression ratio.

Usually to maintain vehicle driveability, the lower the low-end torque, the lower the gear box ratios. As a consequence, with a conventional approach, vehicle consumption cannot obtain full benefits from downsizing (see Fig. 2). A lot of research and development work deals with improvements in low-end torque and reduction of "time to torque", due to the delay that exists between the driver's request and torque output of the engine after a "kick down" [1-3].

Air-charged spark-ignited combustion also presents high knock propensity that requires a lower compression ratio and the use of retarded spark timing. This leads respectively to a 


\begin{tabular}{|c|c|c|}
\hline Chain of efficiency & How to improve & Downsizing \\
\hline Combustion eff. & complete combustion & 0 \\
\hline $\begin{array}{l}\text { Thermodynamic } \\
\text { eff. }\end{array}$ & $\begin{array}{c}1-1 / r_{c}(\gamma-1) \\
\Rightarrow>\text { increase } r_{c} \text { and }\end{array}$ & \\
\hline Cycle eff. & $\begin{aligned}=> & \text { fast combustion } \\
& \text { at TDC } \\
=> & \text { reduce thermal } \\
& \text { transfers } \\
= & \text { reduce pumping }\end{aligned}$ & + \\
\hline Mechanical eff. & $=>$ reduce friction & + \\
\hline
\end{tabular}

Reference $=$ conventional naturally aspirated gasoline engine

+ : advantage of the downsizing approach

- : disadvantage of the downsizing approach

=> : ways for the approach to be improved $r_{c}$ : compression ratio

Figure 1

Improving efficiency of downsizing.

lack of thermodynamic efficiency and cycle efficiency. In order to take full advantage of downsizing, the challenge is then to find a suitable combustion process that is knock resistant keeping in mind the interest for high low-end torque.

\section{THE IFP CONCEPT TO REDUCE GASOLINE $\mathrm{CO}_{2}$ EMISSIONS}

\subsection{Residual Gas Free Combustion Based on Scavenging}

In 1995, IFP has experimented on a new combustion process with high load propensity and high knock resistance thanks to scavenging of residual gases. Two main reasons may lead to knock occurrence:

- a high temperature of the air-fuel mixture during the combustion process;

- the presence of residual burned gases from previous combustion that have a thermal and chemical impact on the fresh mixture and thus increasing knock sensitivity [4].

For high loads at low engine speeds, scavenging of residual gases is performed using the boosted air intake pressure (higher than exhaust back pressure at low engine speeds) and valve overlap between intake and exhaust valves to create at intake top dead centre a period for intake air to push the residual burned gases out of the combustion chamber (Fig. 3). While converting dead volume to useful displacement, scavenging improves not only engine knock resistance but also engine volumetric efficiency which is of great value for low-end torque [5].

\subsection{The IFP View of the Gasoline Engine}

IFP's main strategy regarding downsizing is based on a combustion process with high knock resistance thanks to scavenging of residual burned gases for improving thermal efficiency. Combustion is kept stoichiometric to be compatible with $3 \mathrm{~W}$ cat after-treatment for an environmentally friendly engine. IFP has in mind a full stoichiometric map including maximum power which means depolluted engines on the whole engine map. This approach uses only current and reliable technologies (and especially conventional turbochargers).

This way offers a high $\mathrm{CO}_{2}$ saving potential $-20 \%$ and more ([6-8]) — and, looking to the future, presents high synergy with mild hybridisation for further gain.

Even if for a long time this IFP concept has been associated to GDI and twin-scroll turbine housing (Fig. 4), nowadays, this approach has been adapted to a large panel of engine configurations:

- direct injected or, more recently, port fuel injected (PFI);

- different engine arrangements and especially 3 and 4-cylinder;

- with one or two camphasers (VVT) for controlling scavenging process duration;

- with common (mono-scroll) or twin-scroll turbo (Fig. 4).

\subsection{Which Technologies for Scavenging?}

\subsubsection{Twin-Scroll GDI as the Reference}

At the beginning of the IFP developments, scavenging required the combination of gasoline direct injection, variable 
Fuel consumption map ( $\mathrm{g} / \mathrm{kWh})$

Naturally aspirated SI engine

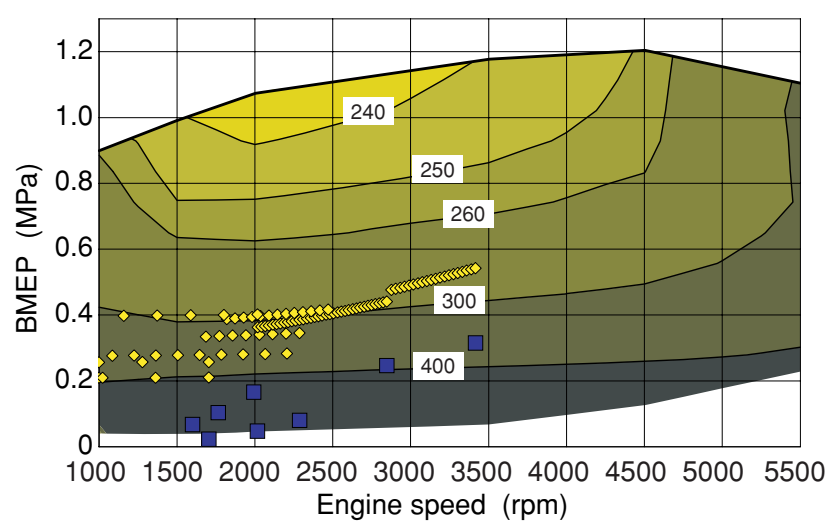

Fuel consumption map (g/kWh) Conventionnel supercharged SI engine

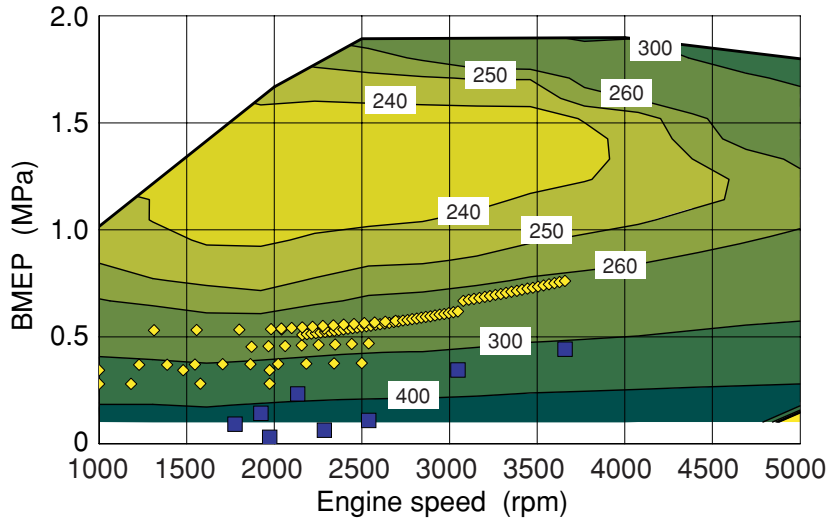

$\diamond$ : Running point in transient behaviour

: Running point in steady state

Figure 2

Comparison of running points between a naturally aspirated engine and a conventional supercharged SI engine during standard New European Driving Cycle NEDC.

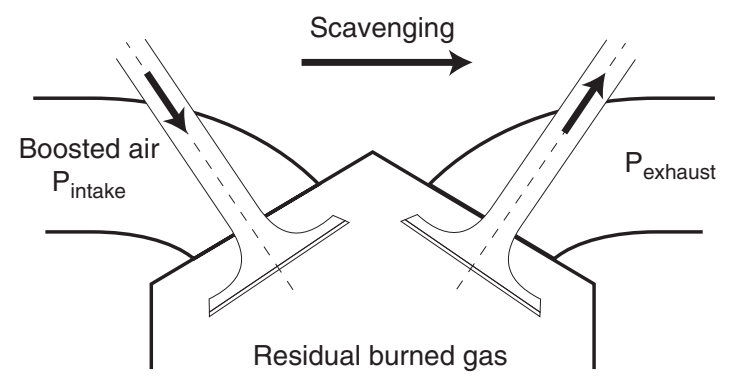

Situation at intake TDC, in case of valve overlap

Figure 3

Residual gases scavenging process (at low engine speed, high load: $\left.P_{\text {int }}>P_{\text {exh }}\right)$

valve timing and twin-scroll turbine housing for 4-cylinder engines. This is the easiest way to perform scavenging for 4cylinder (or V8 engines, bi-turbo). Twin-scroll turbocharger presents a specific layout of its turbine housing in order to separate exhaust gas flows of the different combustion chambers and to reduce cylinder-to-cylinder exhaust flow interaction. With conventional turbo, at the end of cylinder 1 exhaust stroke, for example, the pressure in the exhaust manifold is high due to the beginning of cylinder 3 exhaust stroke. This is not the case with a twin-scroll layout. At intake top-dead-centre, during scavenging process, the pressure difference between intake port and exhaust manifold is thus higher than with conventional turbocharger and the scavenging is more efficient (Fig. 5). The residual burned gases rate is significantly reduced [5].

Gasoline direct injection prevents any fuel from escaping from the combustion chamber directly into the exhaust during the scavenging process. Injection timing is set after exhaust valve closure. In the case of port fuel injection, some fuel will be directly sent into the exhaust thus leading to higher fuel consumption and high $\mathrm{HC}$ emissions.

In order to control the duration of the scavenging process, variable valve timing is required. For this, camphasers are used.

This combination still presents the highest potential in terms of performances but has some drawbacks: first of all cost but also thermal inertia and capability for maximum turbine inlet temperature. Compared with conventional turbo, thermal inertia of twin-scroll housings is increased which in turn increases catalyst light-off duration after cold starts. Moreover, due to the separation strip in the housing, the thermal stress is high, thus limiting the turbocharger capability for very high exhaust gas temperature. 

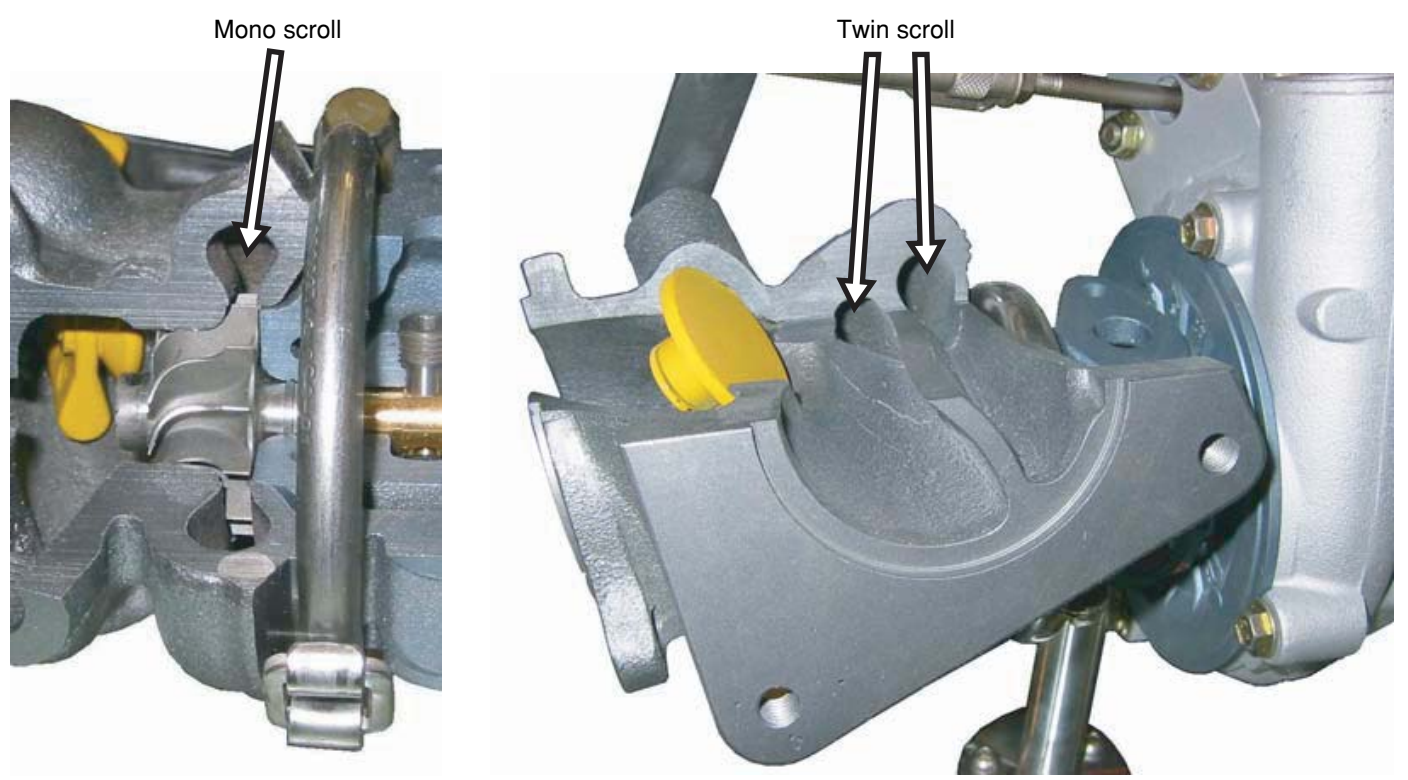

Figure 4

Layouts of mono scroll and twin scroll turbine housings.

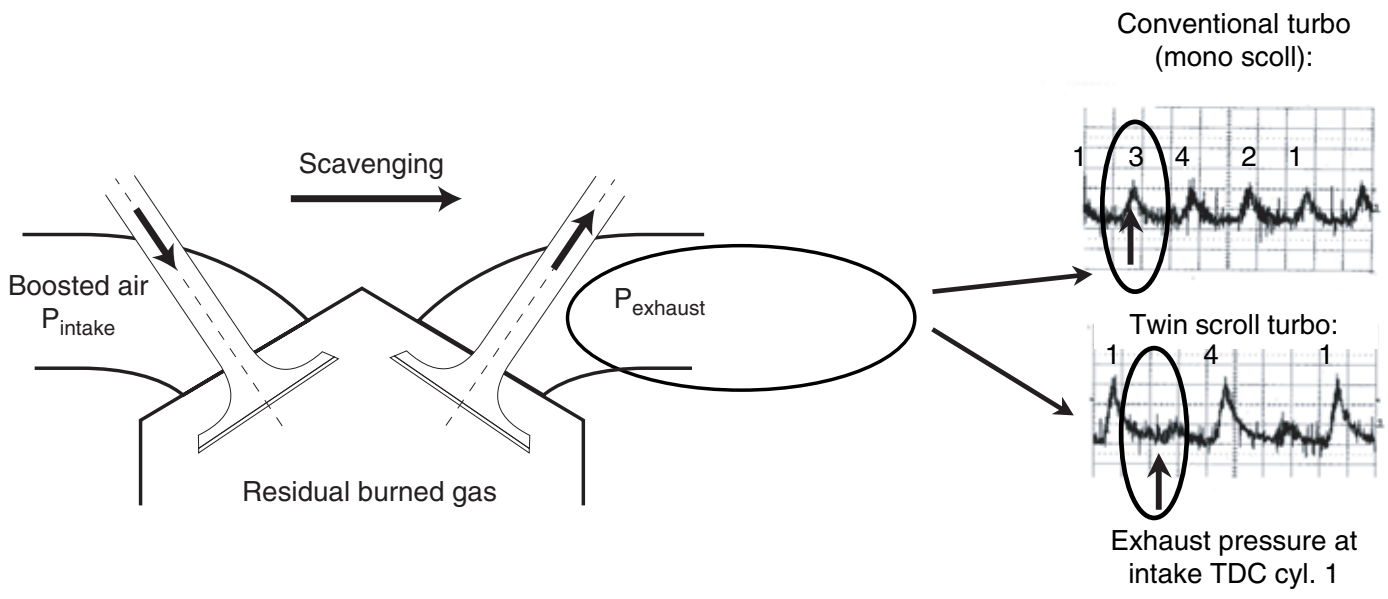

Situation at intake TDC, cylinder 1,

in case of valve overlap

Figure 5

Interest for twin-scroll turbo for better scavenging (4-cylinder or V8 engines).

\subsubsection{Is Scavenging Possible with Mono-Scroll Turbine Housing on 4-Cylinder Engines?}

With mono-scroll turbine housing and conventional exhaust valve event, it has never been possible to scavenge burn gases because of cylinder-to-cylinder interaction (see Fig. 5). Regarding Figure 6, this is the case for small valve overlap but we can see that some scavenging occurs for very large valve overlap. In fact, $\mathrm{O}_{2}$ content in exhaust gases becomes higher than $1 \%$ and volumetric efficiency is improved compared with valve timing without overlapping. This behaviour shows that during valve overlap both scavenging and back flow occur.

Consequently it seems possible to scavenge even with mono-scroll turbine housing on 4-cylinder engines. IFP's development was focused on the exhaust side and in particular on the optimisation of exhaust valve event. With this optimisation, scavenging occurs for smaller valve overlap rather than for conventional valve event. At maximum valve 

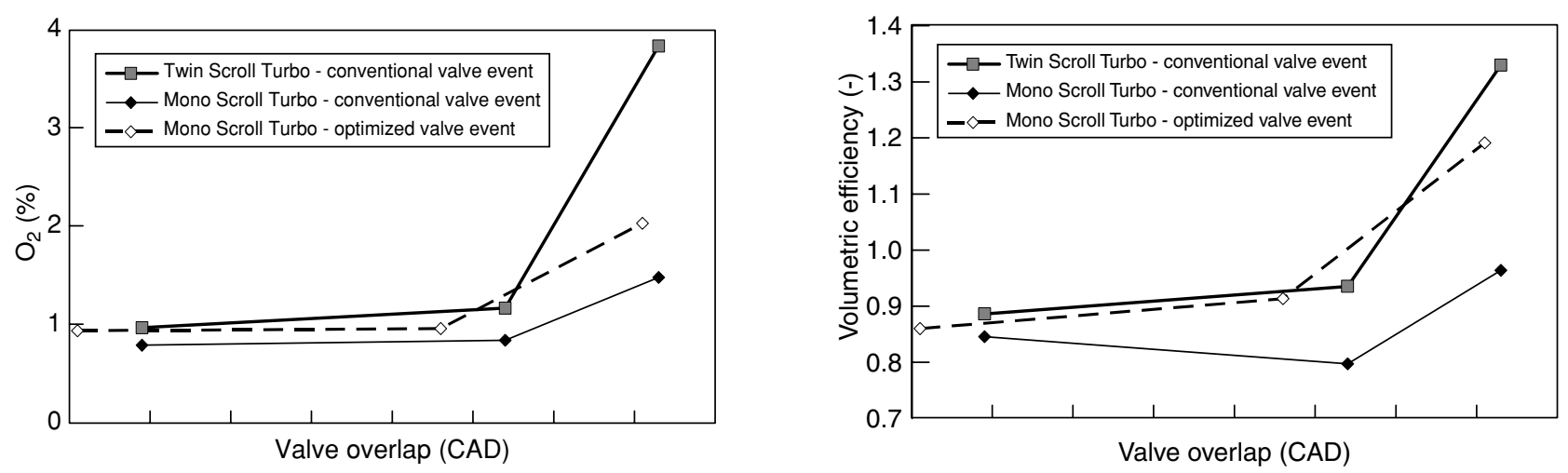

Figure 6

Effect of valve event optimisation on volumetric efficiency and oxygen content in the exhaust gas at $1250 \mathrm{rpm}$.

overlap, air by-pass is not as high as with twin-scroll (exhaust gases contain only $2 \%$ of $\mathrm{O}_{2}$. Scavenging of burned gases is not so bad and engine volumetric efficiency reaches an interesting 1.2 which means that the combustion chamber is free of burned gases.

Finally (Fig. 7), with the same engine and the same centrifugal compressor as the twin-scroll application, the engine reaches 1.59 $\mathrm{MPa} \mathrm{BMEP}$ at $1250 \mathrm{rpm}$ with the optimised valve event in mono-scroll (1.76 in twin-scroll). Compared to the twin-scroll application, there is no loss in power output $(83 \mathrm{~kW} / \mathrm{l})$.

As a conclusion, it is possible to restore scavenging despite the mono-scroll turbine on 4-cylinder engines. Even if low-end torque is a little bit reduced, mono-scroll turbine offers other advantages: lower thermal inertia than twin-scroll turbine and upper maximum temperature at turbine inlet [9]. The latter

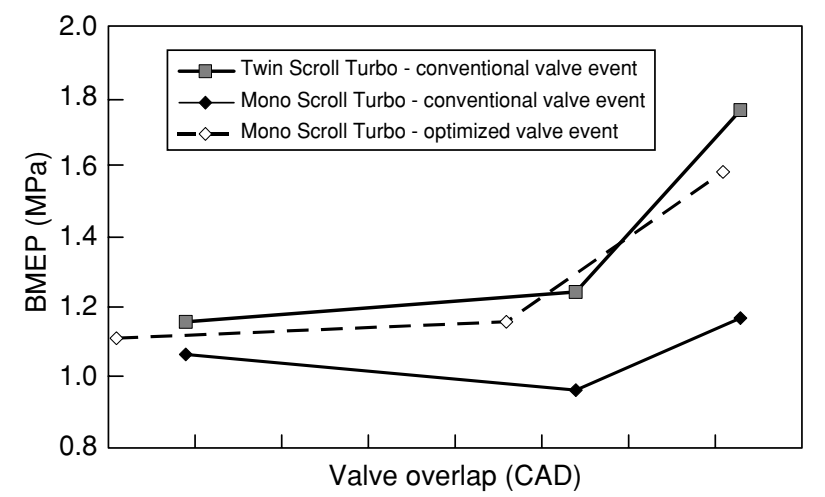

Figure 7

Effect of valve event optimisation: BMEP vs valve overlap at $1250 \mathrm{rpm}$. is not only an advantage from a consumption point of view but also of great interest for reducing pollution when thinking about engines with full lambda 1 map.

\subsubsection{PFI and Scavenging}

More recently, IFP has undertaken in-house research work to develop scavenging in the case of port fuel injection (PFI). A specific layout has been patented for scavenging in the case of a PFI engines in order to avoid HC by-pass during scavenging. The first experiments were carried out in 2003 and confirmed the potential of the approach.

This in-house development was done on a 2 litre engine derived from the Renault mass production 21 turbo ("F4RT"). We kept the same torque and power target as the mass production engine, that is to say $250 \mathrm{Nm}$ and $120 \mathrm{~kW}$. Both objectives were not very high and were easily reached. The most important is to notice the gain on low-end torque. At $1250 \mathrm{rpm}$, when using scavenging, engine performance increases from 1.25 MPa to 1.57 MPa BMEP which represents a $26 \%$ low-end torque increase (see Fig. 9).

Figure 8 illustrates the effect of valve overlap on engine behaviour. Like GDI engines, valve overlap improves engine volumetric efficiency. Fresh air by-pass occurs for large overlapping which can be seen on $\mathrm{O}_{2}$ emissions. In the first steps of valve overlapping, $\mathrm{HC}$ emissions remain constant whereas $\mathrm{O}_{2}$ increases, showing that $\mathrm{HC}$ emissions are not due to scavenging. For very large valve overlap, small HC by-pass appears but in a very low proportion compared to fresh air.

This preliminary work has shown that scavenging with port fuel injection is possible without fuel by-pass. This result is of great interest especially for small engines which cannot afford GDI technology because their cost has to be very low. IFP is still working on the development of PFI scavenging and this has become a major field of its R\&D. 


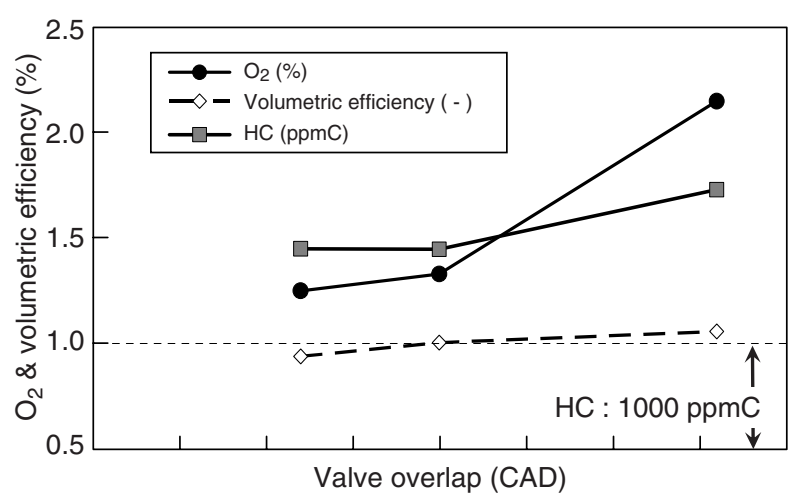

Figure 8:

Effect of valve overlap in the case of PFI engine at $1500 \mathrm{rpm}$.

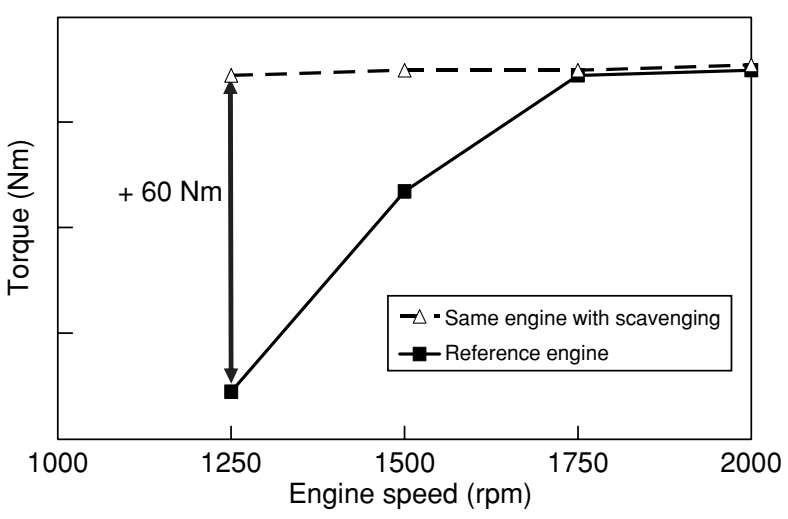

Figure 9

Gain on low-end torque when using scavenging in the case of port fuel injection

\section{FROM TWIN-SCROLL GDI TO MONO-SCROLL PFI?}

\subsection{Engine and Experimental Conditions}

The engine used in this program is an in-line 4-cylinder engine (Table 1). Engine capacity is 1.8 1. Conventional swirl-type direct injectors are implemented. The engine is fitted with two camphasers for conventional variable valve timing (VVT). Ignition coils are pencil type. To enable fast and stable combustion, high air tumble-motion is obtained thanks to tumble type air ducts and a piston with a bowl. A dedicated short duct, low plenum volume, engine air intake system is also fitted [7].

TABLE 1

IFP 1.81 engine features

\begin{tabular}{l|l}
\hline Engine type & In-line 4-cylinder \\
\hline Capacity $\left(\mathrm{cm}^{3}\right)$ & 1783 \\
\hline Bore x stroke $(\mathrm{mm})$ & $82.7 \times 83$ \\
\hline Cylinder head & 4 valve / cyl., tumble shape air ducts \\
\hline Valve train & 2 camphasers (intake and exhaust) \\
\hline Injection system & $\begin{array}{l}\text { Swirl type injectors } \\
5-12 \text { MPa injection pressure }\end{array}$ \\
\hline Combustion type & Homogeneous, stoichiometric \\
\hline Compression ratio & $10.3: 1$ \\
\hline
\end{tabular}

From an experimental point of view, conditions are as follows:

- the relative air/fuel ratio $(\lambda)$ is fixed at 1.0 while upstream turbine temperature in the hottest scroll is below the temperature limit $\left(950^{\circ} \mathrm{C}\right.$ for twin-scroll housing);

- the exhaust back pressure is fixed at almost $45 \mathrm{kPa}$ at maximum power $(5500 \mathrm{rpm})$;
- the intake air temperature is regulated at $25^{\circ} \mathrm{C}+/-1{ }^{\circ} \mathrm{C}$ and hygrometry at $38 \%+/-12 \%$;

- the air temperature in engine intake plenum is regulated at $50^{\circ} \mathrm{C}+/-1^{\circ} \mathrm{C}$ by means of a liquid-cooled intercooler;

- the fuel is an European commercial one, with an equivalent Research Octane Number of 95;

- the ignition timing is set at the knock limit spark advance.

\subsection{Recent Results with the 1.8 I GDI Engine}

When engine downsizing is considered to reduce vehicle consumption, the higher the cubic capacity reduction, the higher the fuel saving. To maintain high driveability for the vehicle, specific performances have to be continuously increased. In the past 4 years, IFP targets have greatly increased: maximum BMEP has passed from 1.6 to $2.4 \mathrm{MPa}$ while power density has increased from 60 to $90 \mathrm{~kW} / \mathrm{l}$ with a simultaneous reduction in engine cost.

The first step in cost reduction was to replace twin-scroll by mono-scroll turbine housing. In this case, one main objective was to maintain engine performance: cost reduction has to have no impact on engine performance especially on lowend torque.

\subsubsection{Mono-Scroll Turbo vs Twin-Scroll Turbo: Full Load Comparison}

Comparison between mono-scroll and twin-scroll turbine housing has been evaluated both on a "torque oriented" application and a "power oriented" application. "Torque" application means a turbocharger matched to $83 \mathrm{~kW} / 1$ and above all targeting very high low-end torque. "Power" version means that the turbocharger matching has been modified to be compatible with power density of $90 \mathrm{~kW} / \mathrm{l}$ but with some drawbacks on low-end torque. In this paper we will focus on the higher targets to compare mono-scroll and twinscroll turbine. 
TABLE 2

Comparison of main performances for mono-scroll and twin-scroll turbo

\begin{tabular}{|c|c|c|c|}
\hline Performance Criteria & \multicolumn{2}{|c|}{ Mono-scroll version } & Twin-scroll version \\
\hline BMEP at $1250 \mathrm{rpm}(\mathrm{MPa})$ & \multicolumn{2}{|c|}{1.26} & 1.45 \\
\hline Engine speed for 2.0 MPa BMEP (rpm) & \multicolumn{2}{|c|}{1650} & 1570 \\
\hline BSFC at max. power $(\mathrm{g} / \mathrm{kWh})$ & $\begin{array}{c}336 \\
\text { (for } 90 \mathrm{~kW} / 1 \text { and } 950^{\circ} \mathrm{C}\end{array}$ & $\begin{array}{c}297 \\
\text { (for } 90 \mathrm{~kW} / \mathrm{l} \text { and } 1050^{\circ} \mathrm{C} \text { ) }\end{array}$ & $\begin{array}{c}332 \\
\text { (for } 90 \mathrm{~kW} / 1 \text { and } 950^{\circ} \mathrm{C} \text { ) }\end{array}$ \\
\hline Lambda value at max. power & $\begin{array}{c}0.79 \\
\left(950^{\circ} \mathrm{C}\right)\end{array}$ & $\begin{array}{c}0.89 \\
\left(1050^{\circ} \mathrm{C}\right)\end{array}$ & $\begin{array}{c}0.80 \\
\left(950^{\circ} \mathrm{C}\right)\end{array}$ \\
\hline
\end{tabular}

In this first comparison, the characteristics of the turbochargers are quite similar:

- the compressor is the same: wheel type and diameter and trim of the housing;

- the turbines are quite similar: same wheel type and diameter but the $\mathrm{a} / \mathrm{r}$ factor of the housing is slightly different because of the different housings: mono or twin-scroll.

Main performance criteria (see Table 2) concern low-end torque capability and BSFC at maximum power. It is important to mention that both versions have been tested with the same limit for the temperature upstream turbine, that is to say $950^{\circ} \mathrm{C}$. In fact, this value is the technological limit for twinscroll turbine housings because of thermal stress on the separation strip. But for mono-scroll turbine housings, this value is not longer a technological limit: turbo charger manufacturers now propose housings that can function with upstream temperatures up to $1050^{\circ} \mathrm{C}$. Consequently, the mono-scroll version has also been tested with a maximum temperature of $1050^{\circ} \mathrm{C}$ at turbine inlet. This is an upper limit that highlights the gain on mixture enrichment and consequently on engine consumption.

If we focus on results obtained with the same inlet temperature limit $\left(950^{\circ} \mathrm{C}\right)$, we can notice that performances obtained are very close, especially at high engine speed. The main difference between the mono-scroll version and the twin-scroll version concerns the low-end torque, especially for engine speed lower than $1750 \mathrm{rpm}$ (see Fig. 10). In fact, the pulsed functioning of the turbine is very important to reach the maximum torque at very low engine speed. With mono-scroll turbine housing, pulse energy recovery is reduced compared to twin-scroll turbine housing which reduces boost pressure. The consequence is a lack of 0.19 MPa BMEP at $1250 \mathrm{rpm}$ (13\%), despite the fact that the scavenging process is quite the same between the two versions thanks to the optimisation of the valve event as previously explained. For engine speed higher than 1750 rpm, performances are quite similar.

Nevertheless, this first result is quite encouraging: the low-end torque reached with the mono-scroll turbo is quite interesting and not so far from the twin-scroll turbo thanks to the scavenging process that has been maintained $\left(\right.$ See $\mathrm{O}_{2}$ emission on Fig. 10). In particular, the maximum BMEP of $2.4 \mathrm{MPa}$ is obtained before $2000 \mathrm{rpm}$, which represent an interesting performance, not reachable with a more conventional approach with mono-scroll turbo.

Concerning the mixture enrichment required to fulfil the temperature limit upstream turbine at $950^{\circ} \mathrm{C}$, it is higher with the mono-scroll turbine at medium engine speed but is finally quite similar at high engine speed and maximum power. This result is particular and is due to the temperature sensors on the upstream turbine. In fact, the measurement of this temperature is the mean value of the two measurements in each scroll of the turbine housing: each sensor receives the flow of two cylinders. But in the mono-scroll configuration, there is only one sensor that receives the flow of the four cylinders. Finally, the thermal stress of the sensors is not the same in both cases. The consequence is that for the same upstream turbine temperature conditions, the downstream turbine temperatures are different: in the case of the mono-scroll version, this temperature is lower by about $20^{\circ} \mathrm{C}$, which is quite important for the enrichment. This explains why the enrichment required for the same upstream turbine temperature conditions is higher with the mono-scroll housing at medium engine speed. At high engine speed and especially at maximum power, the enrichment is quite the same because we benefit from the higher flow capacity of the mono-scroll housing when considering an $\mathrm{a} / \mathrm{r}$ factor quite similar for the two housings.

Consequently, the BSFC comparison follows the same trend: BSFC are quite similar for both versions at high engine speed and especially at maximum power: $336 \mathrm{~g} / \mathrm{kWh}$ for the mono-scroll application versus $332 \mathrm{~g} / \mathrm{kWh}$ for the twin-scroll application. At medium engine speed, the benefit for the twin-scroll application is between 10 and $20 \mathrm{~g} / \mathrm{kWh}$ compared to the mono-scroll one, but this is not really representative for the reasons mentioned above: the exhaust thermal levels are not the same in both cases and are more critical for the mono-scroll version.

If we now look at the results obtained with $1050^{\circ} \mathrm{C}$ maximum inlet turbine temperature, we can see that the mixture enrichment is divided by 2 between 3500 and $5500 \mathrm{rpm}$. At maximum power, improvement in consumption reaches 

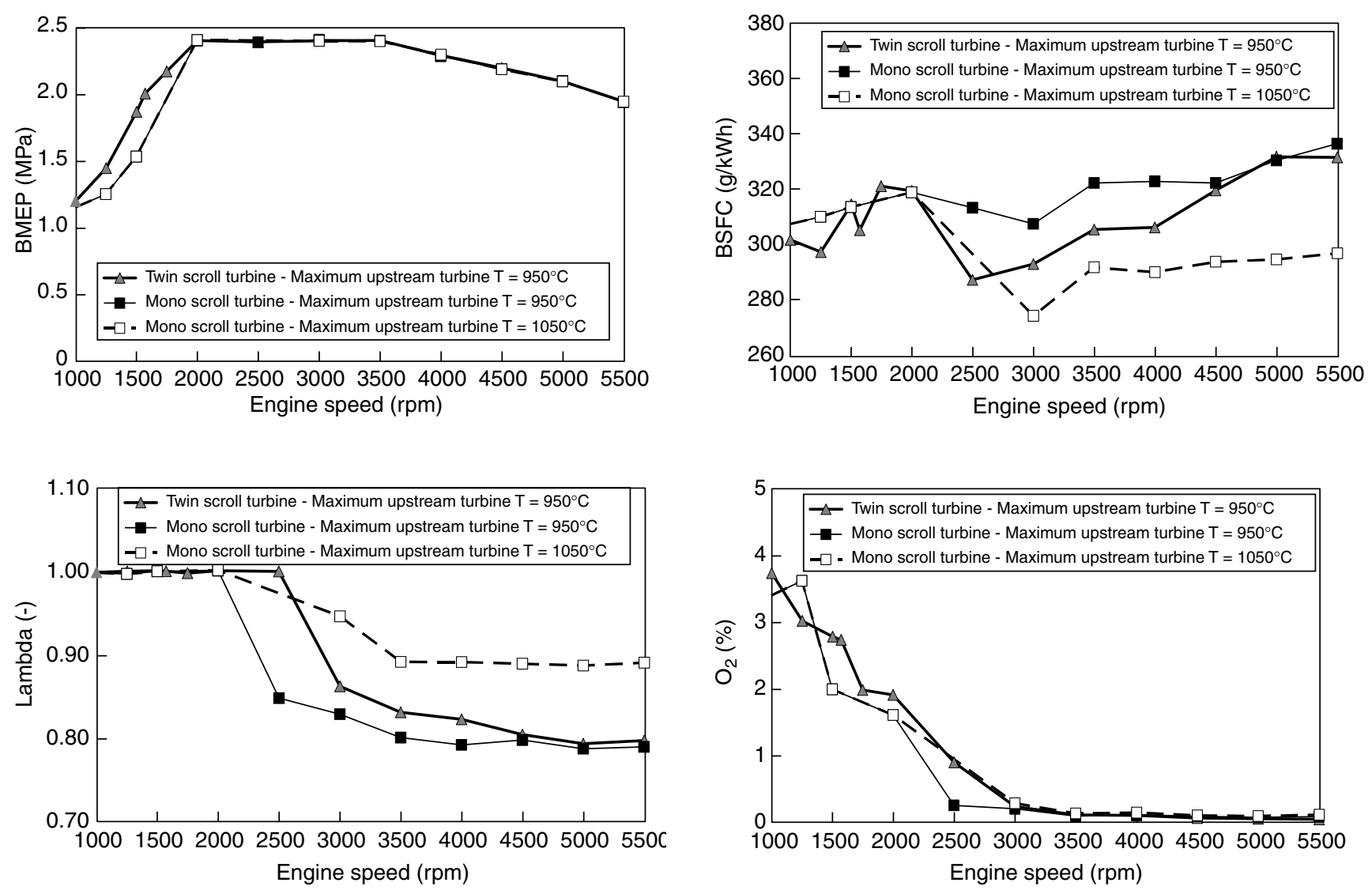

Figure 10

Mono-scroll housing compared to twin-scroll housing, 2.4 MPa BMEP \& 90 kW/l.

$40 \mathrm{~g} / \mathrm{kWh}$ and BSFC at maximum power is lower than $300 \mathrm{~g} / \mathrm{kWh}(297 \mathrm{~g} / \mathrm{kWh})$ which is quite impressive for power density of $90 \mathrm{~kW} / \mathrm{l}$.

\subsubsection{Optimisation of the Turbocharger Matching}

In section 1.3.2 we saw that it is possible to re-establish the scavenging process when using mono-scroll turbine housings on an in-line 4-cylinder engine, and that performances can be very close between the two versions: mono-scroll and twinscroll. In particular, the low-end torque is quite attractive even with a mono-scroll turbo.

On the basis of these results, a new turbocharger matching has been defined, in order to favour the low-end torque. The target was still $2.4 \mathrm{MPa}$ BMEP but power density was reduced to $83 \mathrm{~kW} / \mathrm{l}$.

For this development, the limit on the exhaust temperature has been changed. In fact, the $950^{\circ} \mathrm{C}$ limit on the upstream turbine temperature is not a technological limit for monoscroll turbine, as already mentioned. For this test an $860^{\circ} \mathrm{C}$ limit on the downstream turbine temperature was considered being quite a common value on the exhaust gas maximum temperature for the catalyst systems.

With these conditions, the following performances (see Table 3) have been reached concerning the main criteria:

\section{TABLE 3}

Main performances (maximum downstream turbine temperature: $860^{\circ} \mathrm{C}$ )

\begin{tabular}{l|c}
\hline Performance Criteria & $\begin{array}{c}\text { Mono-scroll Low-end } \\
\text { Torque version }\end{array}$ \\
\hline BMEP @ 1250 rpm (MPa) & 2.0 \\
\hline Engine speed for 2.4 MPa BMEP (rpm) & 1500 \\
\hline BSFC @ max. power (g/kWh) & 289 \\
(for $83 \mathrm{~kW} / \mathrm{l})$
\end{tabular}

With this matching, low-end torque is particularly impressive: 2.0 MPa BMEP are available at $1250 \mathrm{rpm}$, and 2.4 MPa BMEP available at $1500 \mathrm{rpm}$. On the other hand, 

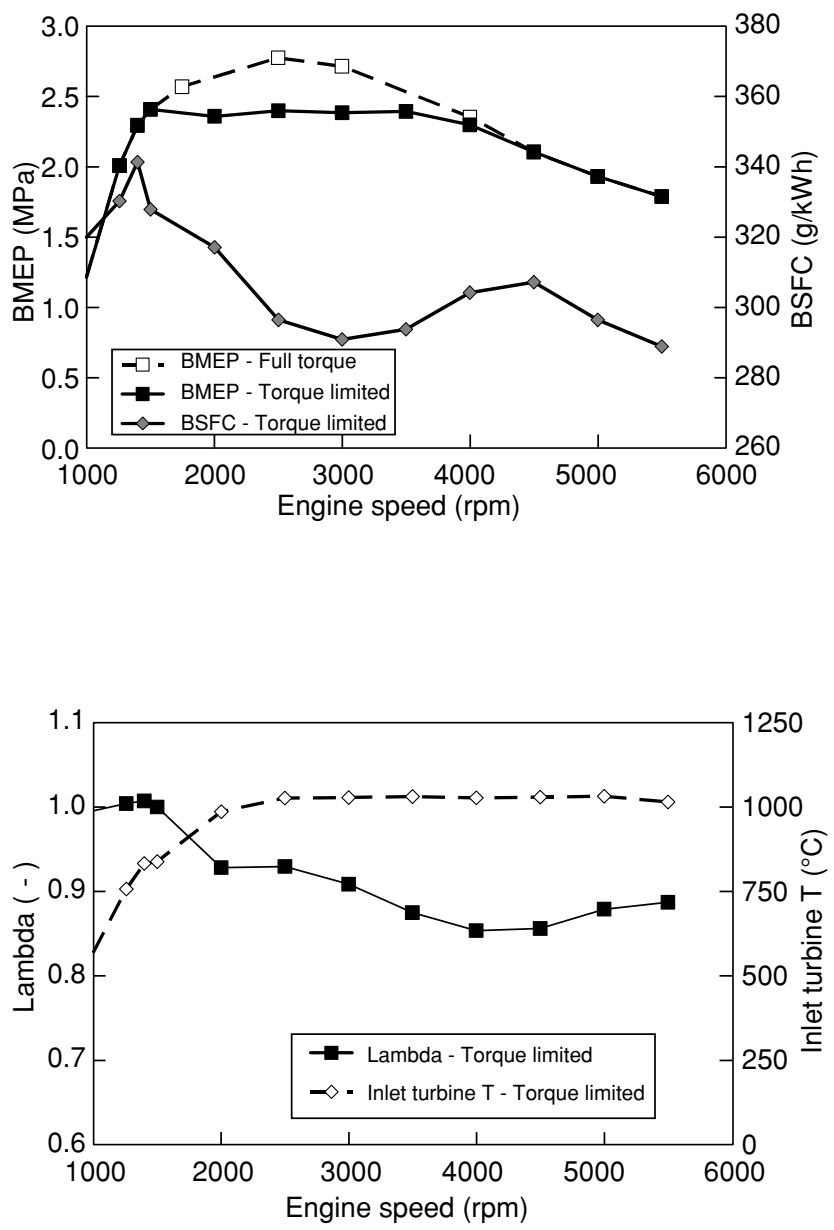

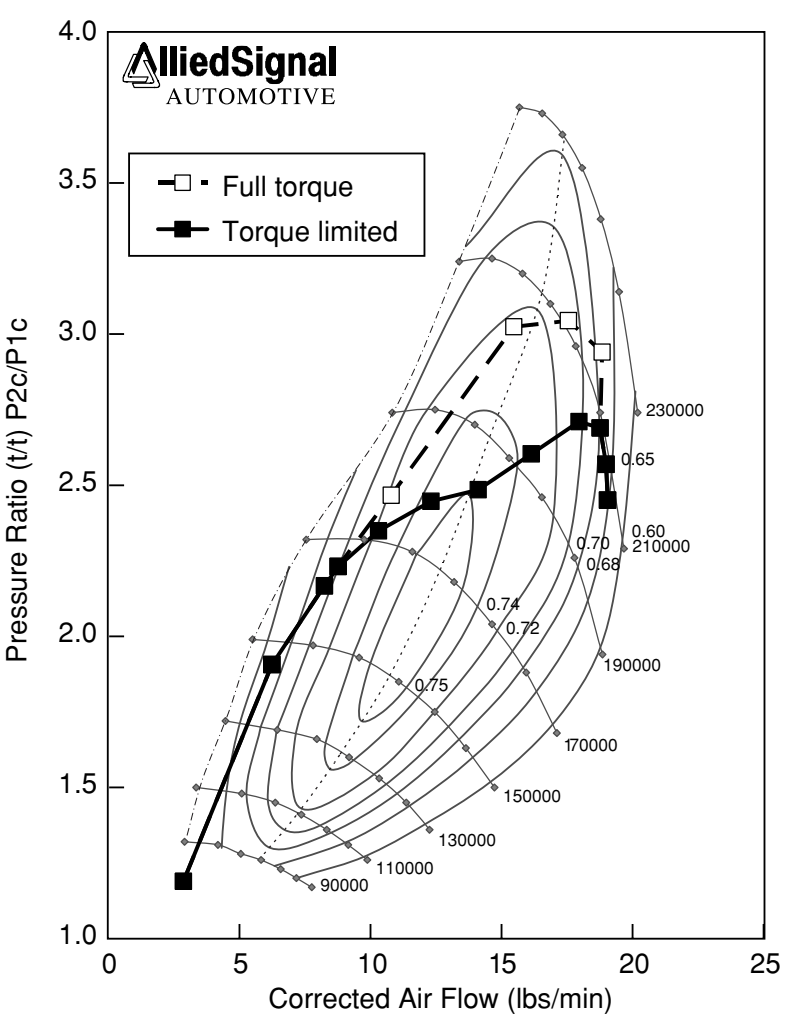

Figure 11

Mono-scroll 2.4 MPa BMEP application (maximum downstream turbine temperature: $860^{\circ} \mathrm{C}$ ) consumption remains very low and acceptable at $289 \mathrm{~g} / \mathrm{kWh}$ at maximum power, $83 \mathrm{~kW} / \mathrm{l}$. This is due to the good lambda value, 0.87 , thanks to the limit at $860^{\circ} \mathrm{C}$ on the downstream turbine temperature. Maximum upstream turbine temperature is then around $1030^{\circ} \mathrm{C}$, which is technologically available at reasonable cost for mono-scroll turbine housings (see Fig. 11). We have to notice that with this turbocharger, the engine can reach very high load (2.77 MPa BMEP at $2500 \mathrm{rpm}$ ) but torque density has been voluntarily limited to $2.4 \mathrm{MPa}$ BMEP.

Concerning fuel consumption, for engine speeds higher than $2000 \mathrm{rpm}$, it is between 289 and $307 \mathrm{~g} / \mathrm{kWh}$, which is a very good result considering the very high load reached. For engine speeds lower than $2000 \mathrm{rpm}$, the consumption appears a little high, with a maximum of $340 \mathrm{~g} / \mathrm{kWh}$ at $1400 \mathrm{rpm}$. This is due in large part to the high scavenging of fresh air in this range of engine speeds: since exhaust gas are stoichiometric (scavenging air flow + trapped mixture), the in cylinder mixture is rich with a great impact on consumption. A good way to reduce this is to run the engine lean at the exhaust, keeping a slightly rich in cylinder mixture to improve knock resistance. It is then possible to reach the same low-end torque with consumption levels below $300 \mathrm{~g} / \mathrm{kWh}$ in this range of engine speed. Finely, the version with maximum lambda one at the exhaust is fully mapped (see Fig. 12).

The consumption map is very attractive: areas of BSFC lower than 250, then 260 and $270 \mathrm{~g} / \mathrm{kWh}$ are very large and cover most of the daily use of the engine. In particular, the area of BSFC lower than $270 \mathrm{~g} / \mathrm{kWh}$ goes to $2.0 \mathrm{MPa} \mathrm{BMEP}$ from $2000 \mathrm{rpm}$ to nearly $4000 \mathrm{rpm}$. For engine speeds lower than $2000 \mathrm{rpm}$ and BMEP higher than 1.0 MPa, the increase of BSFC is due to the fact that we keep exhaust gas stoichiometric in scavenging conditions. For engine speeds higher than $4000 \mathrm{rpm}$ and BMEP higher than 1.0 MPa, the increase is due to the mixture enrichment required to limit the downstream temperature to $860^{\circ} \mathrm{C}$.

Thanks to the optimisation of the valve timing in part load, best BSFC value of the map is $238 \mathrm{~g} / \mathrm{kWh}$ on the operating point: $2000 \mathrm{rpm}, 1.0 \mathrm{MPa}$ BMEP. Moreover, the reference operating point (2000 rpm and 0.2 MPa BMEP) is at $380 \mathrm{~g} / \mathrm{kWh}$. 


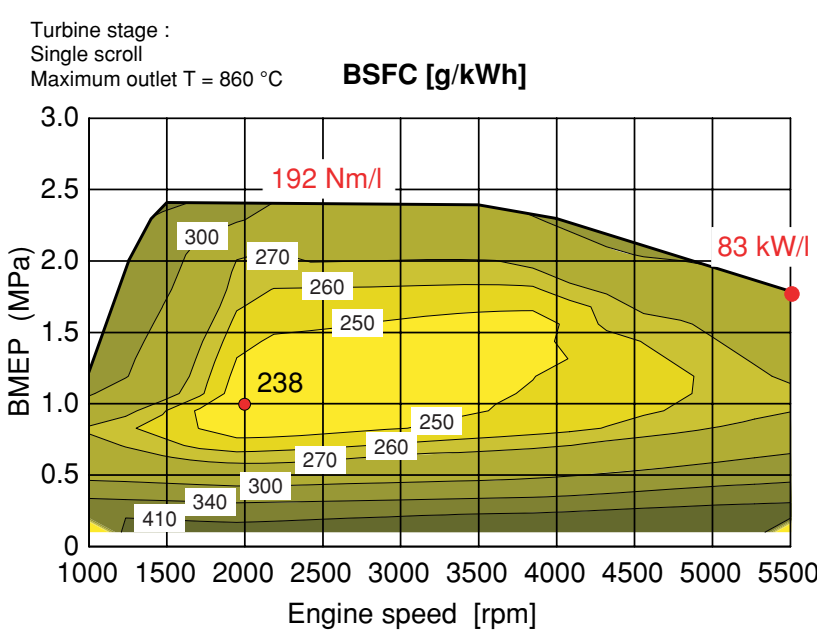

Figure 12

Mono-scroll 2.4 MPa BMEP application, BSFC (g/kWh) map (maximum downstream turbine temperature: $860^{\circ} \mathrm{C}$ ).

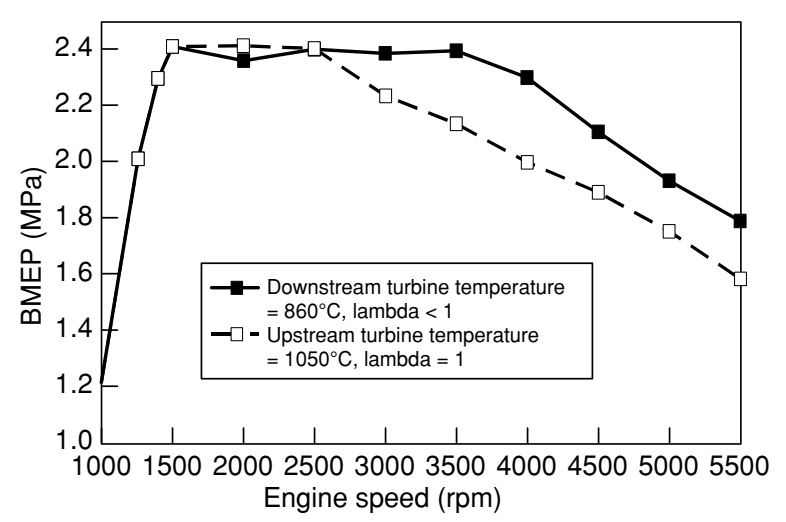

Figure 14

Effect of exhaust temperature and lambda management on $\mathrm{BMEP}(\mathrm{MPa})$.

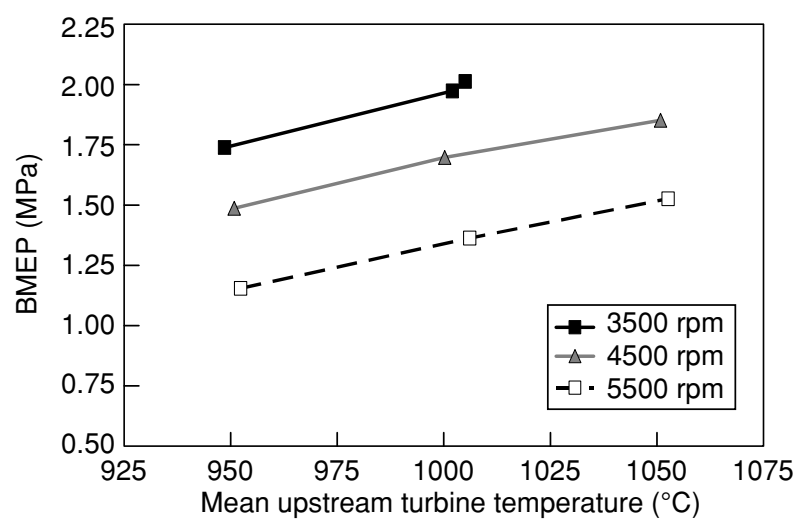

Figure 13

Effect of upstream turbine temperature on maximum load, lambda one.

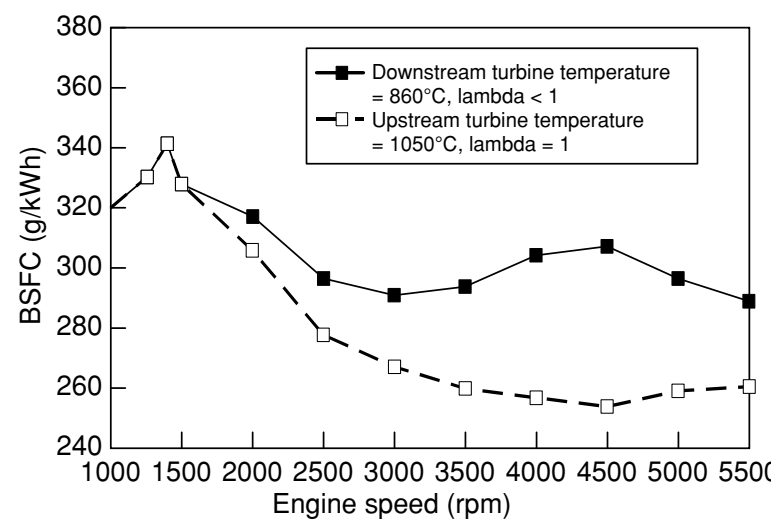

Figure 15

Effect of exhaust temperature and lambda management; $\operatorname{BSFC}(\mathrm{g} / \mathrm{kWh})$.

\subsubsection{Towards a Full Lambda One Map}

Turbo charged gasoline engines require fuel/air mixture enrichment at full load to prevent engine exhaust parts of high thermal stress. This makes the $3 \mathrm{~W}$ catalyst systems inefficient in these conditions. In the future, it could be interesting or even required for gasoline engines to always keep lambda one settings, whatever the engine load.

Considering this, it is interesting to know more precisely the impact of maximum upstream turbine temperature on the maximum load at high engine speed, when keeping lambda one mixture (see Fig. 13).

The gain is around 0.2 MPa BMEP for an increase in the upstream turbine temperature of $50^{\circ} \mathrm{C}$. This gain is quite attractive for a full lambda-one application but not available with twin-scroll turbochargers. Today, at reasonable cost, only mono-scroll turbo chargers are compatible with such temperatures.

In this spirit, the mono-scroll engine version previously described has been fitted with $1050^{\circ} \mathrm{C}$ turbocharger and fullload performances have been limited in order to keep lambda one up to maximum engine speed (see Fig. 14).

In this case, the power is reduced from $83 \mathrm{~kW} / 1$ to $73 \mathrm{~kW} / \mathrm{l}$ but BSFC at maximum power is significantly reduced to an impressive $260 \mathrm{~g} / \mathrm{kWh}$ (see Fig. 15). For engine speed higher than $2500 \mathrm{rpm}, \mathrm{BSFC}$ at full load remains between 254 and $267 \mathrm{~g} / \mathrm{kWh}$ which is a very good result when considering the maximum power. 


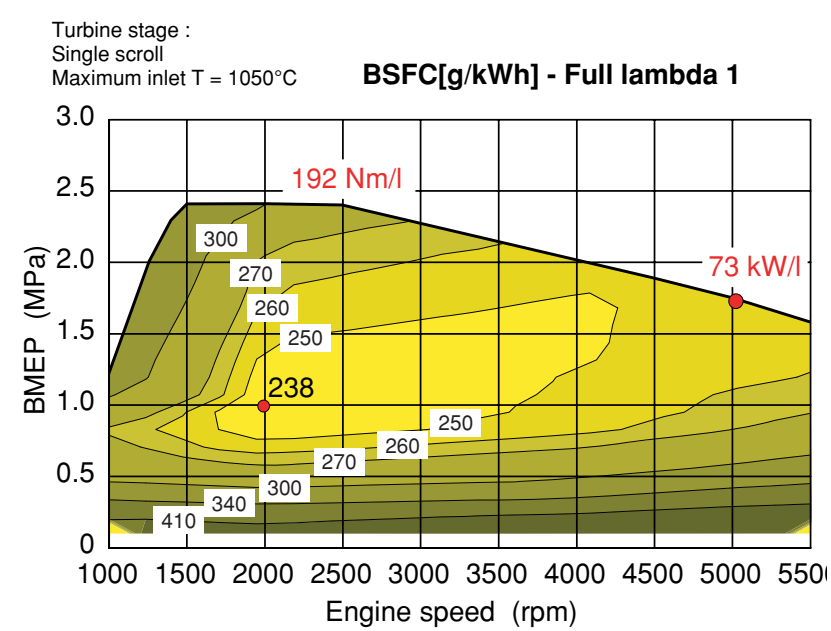

Figure 16

Mono-scroll 2.4 MPa BMEP application, full lambda-one $\mathrm{BSFC}(\mathrm{g} / \mathrm{kWh})$ map (maximum upstream turbine temperature: $\left.1050^{\circ} \mathrm{C}\right)$.

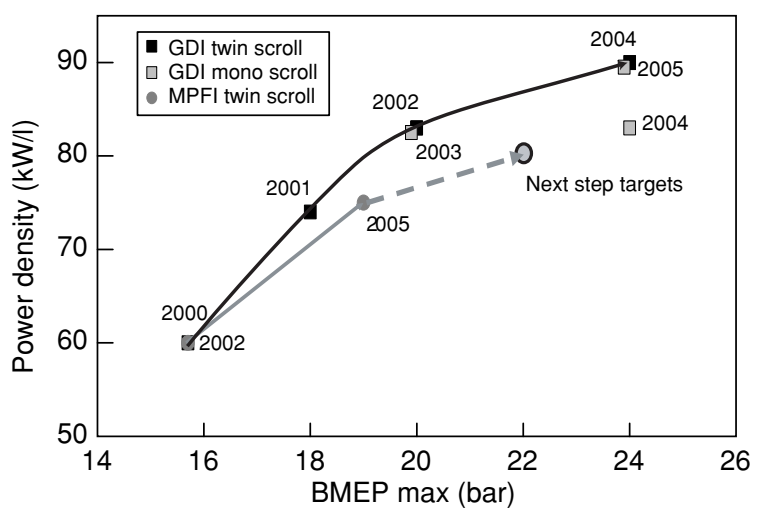

Figure 17

Progression of GDI engine specific performances and targets of PFI application.

Finally, the full lambda-one BSFC map appears particularly interesting and innovative with a very large area of values lower than $260 \mathrm{~g} / \mathrm{kWh}$ (see Fig. 16). This demonstrates the great potential of this kind of approach for gasoline turbo charged engines in the case where pollutants should be treated on the whole map.

\subsection{Potential and Future Prospects for PFI Engines}

We have already seen in section 1.3.3 that IFP works on developing scavenging in the case of port fuel injection. In the early stage of the concept development, targets were limited to the engine baseline performances (F4RT from Renault whose cubic capacity is 2.0 litre): $1.57 \mathrm{MPa}$ BMEP and $60 \mathrm{~kW} / \mathrm{l}$. More recently a great step has been taken not only in terms of performance targets but also in terms of $\mathrm{HC}$ by-pass control. In 2005, the targets were 1.9 MPa BMEP and power density of $75 \mathrm{~kW} / \mathrm{l}$. The torque is reached before $2000 \mathrm{rpm}$. Figure 17 illustrates the progression of BMEP and power density targets for gasoline engines at IFP.

One of IFP's goals is to reduce the gap between GDI and PFI engines. This induces an increase in torque and power density targets. Development of a PFI engine targeting 2.2 MPa BMEP and $80 \mathrm{~kW} / \mathrm{l}$ is under progress, while keeping in mind that improvements in torque and power densities must have no negative effect on low-end torque. IFP is paying careful attention to this last point.

\section{A NEW STEP IN GDI TWIN-SCROLL DEVELOPMENT}

\subsection{Potential of Double Injection at High Load}

GDI technology offers some advantages. One of them is the freedom of fuel injection strategy. Fuel can be totally or partly injected during the compression stroke. This is already the case for a stratified combustion process. When considering a homogeneous combustion, especially for narrow angle concepts where the injector is close to the spark plug in the center of the combustion chamber, the optimum injection timing is generally a balance between fuel evaporation, piston wetting and the cooling effect. Late injections improve the cooling effect and suppress piston wetting but with conventional injection systems, fuel is not completely evaporated when combustion begins. As a consequence, $\mathrm{HC}$ and smoke emissions dramatically increase (Fig. 18).

In the case of supercharged engines operating at lambda one, air/fuel ratio stratification in the combustion chamber can be used to improve engine knock resistance [10]. The mixture is stratified splitting the injection to create a homogeneous phase (early injection) and a stratified mixture close to the spark plug (very late injection). So far, IFP's experience has been that trying to improve GDI engine knock resistance thanks to stratification of the air fuel mixture leads to serious drawbacks on pollutant emissions.

Even with conventional injection systems, engine knock resistance increases when second injection duration increases (Fig. 19). The improvement in combustion timing reaches almost 4 CAD. If we consider no drawbacks on pollutant emissions, the improvement in consumption could be very interesting (10 g/kWh when injecting almost $30 \%$ of the fuel in a late injection). The problem is that the fuel introduced in the combustion chamber during the second injection has not enough time to fully evaporate. When injecting almost $30 \%$ of the fuel during the second injection, pollutant drawback on consumption reaches $7 \mathrm{~g} / \mathrm{kWh}$ and as the consequence there is very little improvement in consumption ("BSFC without pollutant drawback" $=\mathrm{BSFC}-\mathrm{HC}-\mathrm{CO} / 4$, in $\mathrm{g} / \mathrm{kWh}$ ). An increase in the second injection duration still increases pollutant 


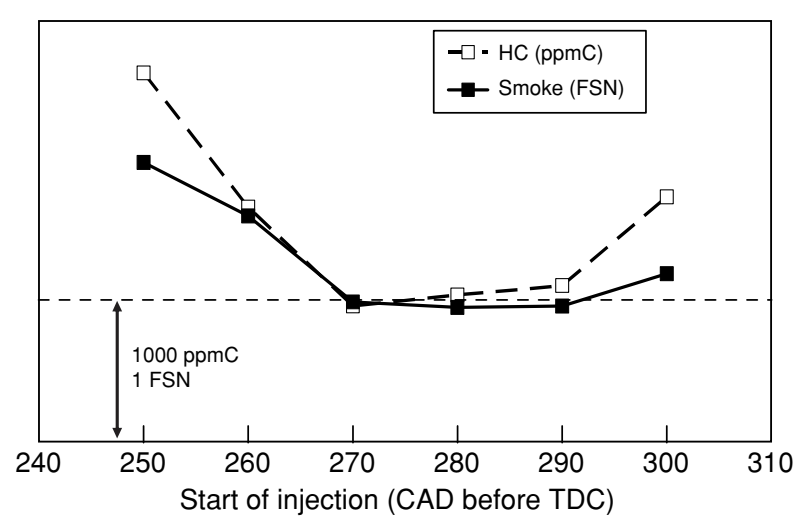

Figure 18

Effect of injection timing on $\mathrm{HC}$ and smoke emissions in the case of single injection. $1500 \mathrm{rpm} \mathrm{1.8} \mathrm{MPa} \mathrm{BMEP.}$

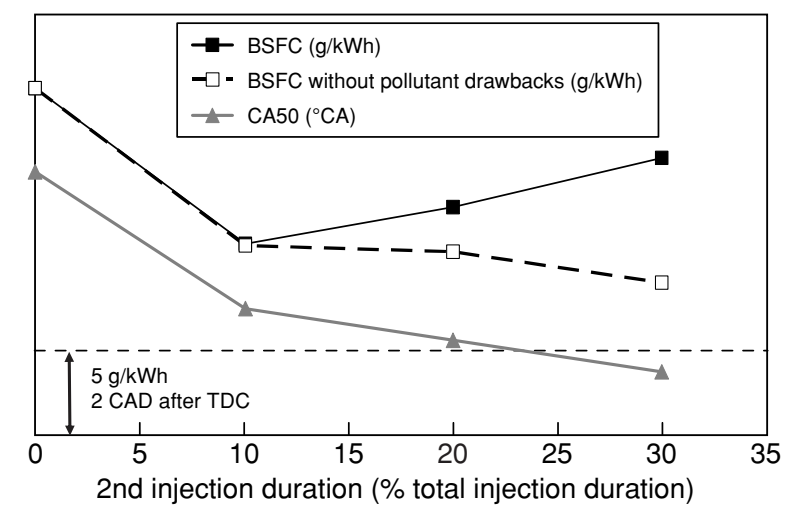

Figure 19

Effect of double injection on engine behaviour with a conventional injection system $-1500 \mathrm{rpm}$ 1.6 MPa BMEPEngine compression ratio $=10.3$. drawbacks and $30 \%$ of fuel introduced during the second injection is the upper limit. For higher values, consumption becomes higher where there is no mixture stratification. As a consequence, to obtain maximum benefit from the potential of lambda stratification, the injection system has to be modified.

\subsection{Improvements in the Injection System - Application on a 2 I Engine with a Compression Ratio of 11.2}

As explained, mixture stratification has some advantages over engine knock resistance when operating at high loads with lambda 1 combustion. In return, $\mathrm{HC}$ and smoke emissions increase greatly.

In order to obtain benefits from this combustion mode at high load, the injection system has been improved to increase fuel evaporation in order to compensate for the short delay between the end of the second injection and the ignition timing. In the meantime, engine compression ratio has been increased from 10.3 to 11.2 to maximise part load efficiency. These tests have been carried out on a 21 version of the engine, still using coupling of GDI, twin-scroll turbine and double VVT. The torque target of this application is $300 \mathrm{Nm}$ which represents $1.89 \mathrm{MPa}$ BMEP.

Figure 20 shows that at $1500 \mathrm{rpm} \mathrm{1.4} \mathrm{MPa} \mathrm{BMEP,}$ lambda stratification has a great effect on combustion timing. Compared to the homogeneous combustion, CA50 is improved by $13^{\circ} \mathrm{CAD}$ for second injection representing $60 \%$ of the total injection duration. This last figure is really impressive, especially because pollutants have no negative effect on engine consumption even with such a long late injection. The improvement in consumption reaches $45 \mathrm{~g} / \mathrm{kWh}$ and is nearly constant from second injection representing 30 to $65 \%$ of the total injection duration.

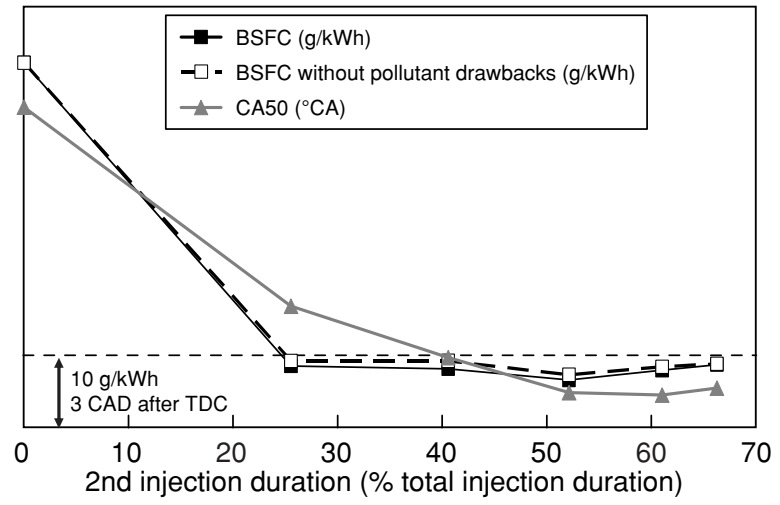

Figure 20

Effect of double injection on engine behaviour with an optimised injection system - $1500 \mathrm{rpm}$ 1.4 MPa BMEP Engine compression ratio $=11.2$.

Regarding full load results (see Fig. 21), it can be seen that when the engine operates in homogeneous combustion, load is limited because of the engine high knock sensitivity due to the 11.2 compression ratio. At $1750 \mathrm{rpm}$, the maximum engine load is only 1.5 MPa BMEP even though the engine benefits from scavenging. The engine reaches the torque target only at $3000 \mathrm{rpm}$. The use of lambda 1 stratified combustion allows for a great improvement in low-end torque. First engine speed for 1.89 MPa BMEP is reduced from $3000 \mathrm{rpm}$ to $1500 \mathrm{rpm}$. At $1500 \mathrm{rpm}$ an impressive gain, when using lambda stratification, is a torque output increased by $36 \%$ with a $9 \%$ improvement in engine efficiency. 

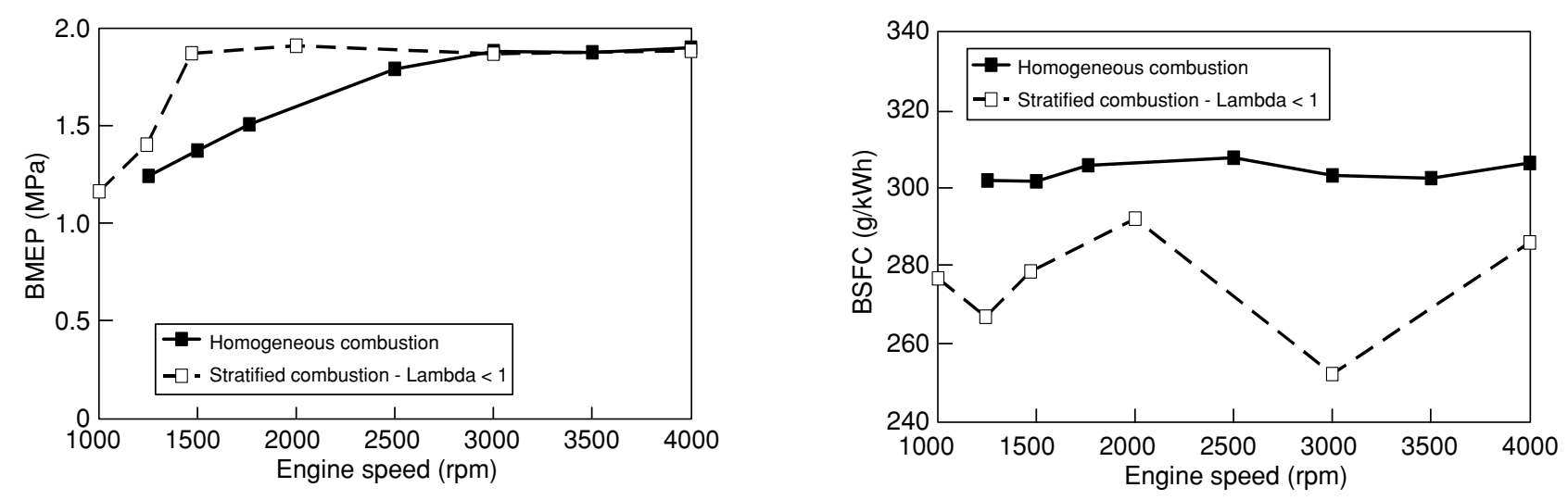

Figure 21

Improvement in low-end torque and engine consumption using lambda 1 stratified combustion.

In conclusion, splitting injection between a conventional injection (homogeneous phase) and a late injection (stratified mixture) allows for great improvement in knock resistance. IFP has implemented a new injection technology on a 21 engine with a very high compression ratio and managed to maintain engine performance. It could also have been used to further increase the 1.81 engine performance with a 10.3 compression ratio.

\section{CONCLUSION}

Downsizing and turbocharging gasoline engines is a short term, efficient way for reducing $\mathrm{CO}_{2}$ emissions. Based on a high knock resistant, residual gas-free combustion process, IFP's approach uses stoichiometric mixture combined with a $3 \mathrm{~W}$ cat. This offers a guarantee of reliable, low emission vehicles in every driving condition, including real driving conditions outside the standard driving cycle. This approach presents a promising cost to benefit ratio.

IFP develops its concept in two different ways: on the one hand IFP still works to increase engine power and low-end torque densities and on the other hand it tries to apply the scavenging process to low cost technologies such as monoscroll turbines or port fuel injection. Performances reached with GDI and twin-scroll turbine housings can be seen as the upper limit for gasoline engines that other technologies have to target.

Currently, when exploiting IFP's approach with GDI, double VVT and twin-scroll turbines, the engine performs 2.0 MPa BMEP at $1340 \mathrm{rpm}$ and $83 \mathrm{~kW} / 1$ or $2.4 \mathrm{MPa}$ BMEP at $2000 \mathrm{rpm}$ and $90 \mathrm{~kW} / \mathrm{l}$. In both cases, the IFP 1.81 engine has a 10.3 compression ratio and conventional GDI injection system. More recently, IFP has implemented a higher pressure injection system to improve engine knock resistance thanks to stratification of the mixture while keeping global stoichiometric combustion. Tests have been carried out on a 21 engine with an 11.2 compression ratio whose BMEP is limited to $1.37 \mathrm{MPa}$ at $1500 \mathrm{rpm}$ due to knocking. When using mixture stratification, the engine reaches $1.89 \mathrm{MPa}$ BMEP at the same engine speed without any drawbacks on pollutant emissions which represents an impressive $38 \%$ increase in low-end torque.

To reduce engine cost, IFP has recently been experimenting in two different ways: replacement of twin-scroll turbine housing by mono-scroll turbine housing for 4-cylinder engine and development of the scavenging process in the case of port fuel injection. Scavenging with mono-scroll turbine housings can be maintained thanks to an optimisation of exhaust valve event. The 1.81 engine with a 10.3 compression ratio performs $2.4 \mathrm{MPa} \mathrm{BMEP}$ at $1400 \mathrm{rpm}$ and $83 \mathrm{~kW} / \mathrm{l}$ or 2.4 MPa BMEP at $2000 \mathrm{rpm}$ and $90 \mathrm{~kW} / \mathrm{l}$; performances equivalent to twin-scroll versions. Mono-scroll turbines have some slight drawbacks on engine specific consumption and on low engine speed performances because such turbines cannot benefit from pulse energy recovery as much as twinscroll turbines. However mono-scroll turbines offer advantages especially very high maximum inlet temperature (above $1050^{\circ} \mathrm{C}$ ) whereas twin-scroll turbines are limited to $950^{\circ} \mathrm{C}$. Of course, increasing maximum engine outlet temperature will have a big effect on engine cost (turbine, exhaust valves and manifold). It allows for high fuel saving : the potential of this engine in full lambda 1 operation is 2.4 MPa BMEP at $1400 \mathrm{rpm}$ and an impressive $73 \mathrm{~kW} / \mathrm{l}$ with $260 \mathrm{~g} / \mathrm{kWh}$ BSFC. With such performances it is possible to produce an environmentally friendly engine, which is one of IFP's goal:

- engines with efficient after-treatment on the whole engine map;

- low $\mathrm{CO}_{2}$ emissions thanks to a high downsizing rate. 
Last but not least, IFP has adapted its approach to port fuel injection engines. This approach is in its very early stages and has already shown potential. Compared to current engines without scavenging, low-end torque has been improved by $30 \%$. The challenge is to avoid fuel by-pass during scavenging. Current results confirm that it is possible to suppress fuel by-pass with a dedicated engine that opens the door to very interesting outlooks.

\section{ACKNOWLEDGEMENTS}

Many thanks to Honeywell-Garrett for having provided most of the turbochargers for this program.

\section{REFERENCES}

1 Sonner M., Wurms R., Kuhn M. and Friedrich J. (2002) Elektrisch unterstützte Aufladekonzepte beim OttoTurbomotor - Chancen und Grenzen, 8. Aufladetechnische Konferenz, Dresden.

2 Hauet B. and Maroger Y. (2002) Engine Downsizing, a contribution to green house effect reduction, ATA international conference Spark ignition engine: the $\mathrm{CO}_{2}$ challenge, Venice.
3 Rauscher M., Habermann K., Lang O. and Rohs H. (2002) Massnahmen zur Verbesserung des Anfahrdrehmomentes bei aufgeladenen Ottomotoren, 8. Aufladetechnische Konferenz, Dresden.

4 Prabhu S.K., Li H., Miller D.L. and Cernansky N.P. (1993) The effect of nitric oxide on autoignition of a primary reference fuel blend in a motored engine, SAE 932757.

5 Ranini A. and Monnier G. (2001) Turbocharging a Gasoline Direct Injection Engine, SAE 2001-01-736.

6 Lecointe B. and Monnier G. (2003) Downsizing a gasoline engine using turbocharging and direct injection, SAE 200301-0542.

7 Leduc P., Dubar B., Ranini A. and Monnier G. (2003) Downsizing of gasoline engine: an efficient way to reduce $\mathrm{CO}_{2}$ emissions, Oil and Gas Science and Technology - Rev. IFP, $\mathbf{5 8}$

8 Fraidl G.K., Kapus P. and Piock W. (2005) The turbocharged GDI - The competitor to the diesel engine?, Internationales Wiener Motorensymposium, Vienna.

9 Leduc P., Pagot A., Gautrot X. and Schmidt O. (2004) GDI turbocharged engines: mono-scroll or twin-scroll turbine housing?, 9th Aufladetechnische Konferenz, Dresden.

10 Sens M., Sauerstein R., Dingel D., Kahrstedt (2004) Changes and specials to realise a downsizing concept using gasoline direct injection, 9th Aufladetechnische Konferenz, Dresden.

Final manuscript received in January 2006

Copyright (C) 2006 Institut français du pétrole

Permission to make digital or hard copies of part or all of this work for personal or classroom use is granted without fee provided that copies are not made or distributed for profit or commercial advantage and that copies bear this notice and the full citation on the first page. Copyrights for components of this work owned by others than IFP must be honored. Abstracting with credit is permitted. To copy otherwise, to republish, to post on servers, or to redistribute to lists, requires prior specific permission and/or a fee: Request permission from Documentation, Institut français du pétrole, fax. +33147527078 , or revueogst@ifp.fr. 